\title{
Lithium halide and lithium perchlorate binding to phosphates : a multinuclear nuclear magnetic resonance spectroscopic study
}

Citation for published version (APA):

van Lier, J. J. C., Ven, van de, L. J. M., Haan, de, J. W., \& Buck, H. M. (1983). Lithium halide and lithium perchlorate binding to phosphates : a multinuclear nuclear magnetic resonance spectroscopic study. Journal of Physical Chemistry, 87(18), 3501-3509. https://doi.org/10.1021/j100241a029

DOI:

10.1021/j100241a029

Document status and date:

Published: 01/01/1983

Document Version:

Publisher's PDF, also known as Version of Record (includes final page, issue and volume numbers)

Please check the document version of this publication:

- A submitted manuscript is the version of the article upon submission and before peer-review. There can be important differences between the submitted version and the official published version of record. People interested in the research are advised to contact the author for the final version of the publication, or visit the DOI to the publisher's website.

- The final author version and the galley proof are versions of the publication after peer review.

- The final published version features the final layout of the paper including the volume, issue and page numbers.

Link to publication

\footnotetext{
General rights

- You may freely distribute the URL identifying the publication in the public portal. follow below link for the End User Agreement:

www.tue.nl/taverne

Take down policy

If you believe that this document breaches copyright please contact us at:

openaccess@tue.nl

providing details and we will investigate your claim.
}

Copyright and moral rights for the publications made accessible in the public portal are retained by the authors and/or other copyright owners and it is a condition of accessing publications that users recognise and abide by the legal requirements associated with these rights.

- Users may download and print one copy of any publication from the public portal for the purpose of private study or research.

- You may not further distribute the material or use it for any profit-making activity or commercial gain

If the publication is distributed under the terms of Article $25 \mathrm{fa}$ of the Dutch Copyright Act, indicated by the "Taverne" license above, please 


\title{
Lithlum Halide and Lithlum Perchlorate Binding to Phosphates. A Multinuclear Magnetlc Resonance Spectroscopic Study
}

\author{
Johan J. C. van Ller, " Leo J. M. van de Ven, Jan W. de Haan, and Henk M. Buck \\ Laboratories of Organle Chemistry and Instrumental Anatysis, University of Technology, Eindhoven, The Netherlands \\ (Recelved: June 7, 1982; In Final Form: November 4, 1982)
}

Previous work in this laboratory indicated the formation of neutral pentacoordinated phosphorus intermediates during dealkylation reactions in salt-phosphate aggregates. In the present paper we describe the retardation in the rate of phosphorylation toward methanol revealed by kinetic data on 2-methoxy-2-oxo-4,5-dimethyl1,3,2-dioxaphosphol-4-ene (2) upon addition of an equimolar amount of $\mathrm{LiX}(\mathrm{X}=\mathrm{F}, \mathrm{Cl}, \mathrm{Br}$ ) in deuteriochloroform. The nature of interactions of $\mathrm{LiX}\left(\mathrm{X}=\mathrm{F}, \mathrm{Cl}, \mathrm{Br}, \mathrm{ClO}_{4}\right)$ with 2-isopropoxy-2-oxo-5-methyl-1,2-oxaphosphol-4-ene (1), compound 2, triphenyl phosphate (3), and triethyl phosphate (4) in acetone and, in some cases in tetrahydrofuran (THF), were studied by means of multinuclear NMR spectroscopy. The results obtained by the various types of NMR measurements are discussed and put into perspective, both mutually and in relation with the kinetic data. ${ }^{7} \mathrm{Li}$ NMR chemical shift and line broadening data reveal complexation of the phosphoryl oxygen atom by the $\mathrm{Li}^{+}$ion. All four phosphorus compounds investigated here show a preference for 1:1 complexation (salt-phosphate). ${ }^{1} \mathrm{H}$ NMR spectra of 1 in acetone and benzene with lithium bromide reveal moderate changes in the chemical shift of the ring methylene protons. The changes in the geminal coupling constants were small, which indicates negligible differences in the net atomic charges on the phosphorus atom. ${ }^{35} \mathrm{Cl}$ and ${ }^{81} \mathrm{Br} \mathrm{NMR}$ data on salt-phosphate aggregates reveal a fast equilibrium in the complex and a line broadening effect upon complexation. From ${ }^{31} \mathrm{P}$ NMR, the absence of covalent PF bonds could be demonstrated for the combination $2 / \mathrm{LiF}$ in tetrahydrofuran. Some of our conclusions are corroborated by the results of quantum chemical calculations.

\section{Introduction}

Growing recognition of the importance of biologically relevant metal-ion interactions with nucleic acids and nucleotides has stimulated research focused on the chemistry of the complexes formed. ${ }^{1-4}$ Interactions between alkaline-earth metal species and nucleosides (without phosphate groups) are weak and can be explained with only a few specified binding criteria. ${ }^{5,6}$ In nucleic acids, the phosphate-to-metal bonding dominates. Recent $a b$ initio studies of interactions of $\mathrm{Li}^{+}, \mathrm{Na}^{+}, \mathrm{Be}^{2+}$, and $\mathrm{Mg}^{2+}$ with $\mathrm{H}_{2} \mathrm{PO}_{4}^{-}$reveal significant electron transfer for all complexes, except those involving $\mathrm{Na}^{+}{ }^{7}$ This implies that these interactions are not totally electrostatic. On the other hand, ion pairs in organic solvents have been studied thoroughly by combinations of multinuclear NMR techniques. ${ }^{8,9}$ Previous work in this laboratory ${ }^{10}$ provided strong evidence for the involvement of neutral pentacoordinated phosphorus intermediates during dealkylation reactions proceeding via salt-phosphate aggregates in media with low dielectric constants. We therefore decided to investigate the nature of the interaction of lithium halides and lithium perchlorate with model phosphates and a model phosphonate in acetone by means of multinuclear NMR.

(1) Marzilli, L. G. Prog. Inorg. Chem. 1977, 23, 255.

(2) Hodgson, D. J. Prog. Inorg. Chem. 1977, 23, 211.

(3) Swaminathan, V.; Sundaralingam, M. CRC Crit. Rev. Biochem. $1979,6,245$.

(4) Martin, R. B. In "Metal Ions in Biological Systems"; Sigel, H., Ed.; Marcel Dekker: New York, 1979; Vol. 8.

(5) Marzilli, L. G.; de Castro, B.; Caradonna, J. P.; Stowart, R. C.; Van Vuuren, C. P. J. Am. Chem. Soc. 1980, 102, 916.

(6) Strauss, U. P.; Helfgott, C.; Pink, H. J. Phys. Chem. 1967, 71, 2550.

(7) Liebmann, P.; Loew, G.; McLean, A. D.; Pack, G. R. J. Am. Chem. Soc. 1982, 104, 691.

(8) Cahen, Y. M.; Handy, P. R.; Roach, E. T.; Popov, A. I. J. Phys. Chem. 1975, 79, 80 .

(9) Weingărtner, H.; Hertz, H. G. Ber. Bunsenges. Phys. Chem. 1977, 81,1204 .

(10) Castelijns, A. M. C. F.; van Aken, D.; Schipper, P.; van Lier, J. J. C.; Buck, H. M. Recl. Trav. Chim. Pays-Bas 1980, 99, 380
To gain more insight into the nature of the salt-phosphate interaction, ${ }^{1} \mathrm{H}$ NMR spectra of the cyclic phosphonate 1 (Figure 1) in a number of organic solvents (with and without lithium salt) would be helpful. Also, ${ }^{7} \mathrm{Li},{ }^{35} \mathrm{Cl}$, and ${ }^{81} \mathrm{Br}$ NMR spectra of the salt-phosphate complexes can yield valuable information regarding the nature of the complexes. Here, we report chemical shift data of the ${ }^{7} \mathrm{Li}$ nuclei and line width data for ${ }^{35} \mathrm{Cl}$ and ${ }^{81} \mathrm{Br}$ of salts, dissolved in acetone-phosphate mixtures. These data and the solvent- and salt-dependent nonequivalence of the methylene protons in 2-isopropoxy-2-oxo-5-methyl-1,2oxaphosphol-4-ene (1, Figure 1) correspond with the close-ion-pair theory of Popov $^{8}$ and Weingärtner and Hertz. ${ }^{9}$ Besides the study of aggregates by physical means, it also appeared worthwhile to investigate the effect of lithium halides on the rate of phosphorylation of model compound 2.

Bromine anions cause a remarkable decrease in the rate of phosphorylation toward methanol in the different cyclic compounds studied. ${ }^{11}$ In order to establish if this retardation is a more general property of halogen anions in some organic solvents, detailed kinetic data of the complex system $\mathrm{LiX}(\mathrm{X}=\mathrm{F}, \mathrm{Cl}, \mathrm{Br}$ )/2-methoxy-2-oxo-4,5-dimethyl-1,3,2-dioxaphosphol-4-ene (2, Figure 1)/methanol in deuteriochloroform were determined.

\section{Experimental Section}

Reagents. Lithium perchlorate, lithium bromide, lithium chloride, lithium fluoride, and potassium fluoride (Merck AG, Darmstadt) were azeotropically refluxed (benzene) with a special adapter until no water could be removed. Evaporation of the dry solvent in vacuo under nitrogen yielded the dry salt. After drying, all the lithium salts were stored under dry nitrogen atmosphere. 2-Isopropoxy-2-oxo-5-methyl-1,2-oxaphosphol-4-ene (1) was prepared from the corresponding chlorooxaphospholene. ${ }^{10}$

(11) Castelijns, A. M. C. F. Ph.D. Thesis, Eindhoven University of Technology, Eindhoven, The Netherlands, 1979. 

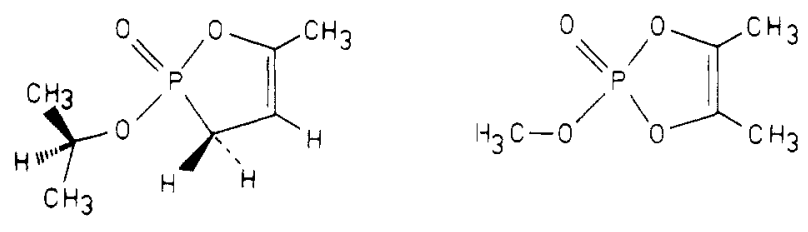

2

Figure 1. Model compounds 1-4.

2-Methoxy-2-oxo-4,5-dimethyl-1,3,2-dioxaphosphol-4-ene (2) was prepared by the procedure described by Ramirez et al. ${ }^{12}$ Triphenyl phosphate $(3$, Aldrich) was azeotropically dried (benzene solution; water was removed by a special adapter) and evaporated to dryness just before use. Triethyl phosphate (4, Aldrich) and the cyclic organophosphorus compounds $(1,2)$ were freshly distilled under reduced pressure before use.

Solvents. Acetone (Merck) was distilled over Drierite and further dried over molecular sieves. Methanol (Merck) was first fractionally distilled from calcium hydride in a nitrogen atmosphere and stored over molecular sieves (3 $\AA)$. Tetrahydrofuran (Merck) was fractionally distilled from calcium hydride in a nitrogen atmosphere. All deuterated solvents used were stored over molecular sieves.

Solutions. In view of the hygroscopicity of solvents and of lithium salts, all solutions were freshly prepared and the NMR tubes were filled under nitrogen atmosphere. NMR spectra of salt-phosphate complexes were obtained immediately after sample preparation. In this way, the influence of dealkylation reactions on chemical shifts and line width data could be neglected.

NMR Measurements. NMR spectra were obtained by using a Bruker WM-250 multinuclear spectrometer operating at a field strength of 5.7 T. For lithium-7 (97.21 $\mathrm{MHz}$ ) chemical shift data were measured against an aqueous $4.0 \mathrm{M} \mathrm{LiClO}_{4}$ solution. Line widths were of the order of $2 \mathrm{~Hz}$. The accuracy of measurement was $\pm 0.2 \mathrm{~Hz}$.

Chlorine-35 spectra were obtained at a frequency of $24.507 \mathrm{MHz}$. Line broadening functions in the ranges 3 , 10 , and $50 \mathrm{~Hz}$ were used, depending on the line width to be observed.

Bromine-81 spectra were obtained at a frequency of $67.55 \mathrm{MHz}$. Line broadening parameters were set at 100 $\mathrm{Hz}$.

Line widths of the chlorine- 35 and bromine- 81 resonances were determined with an estimated accuracy of $\pm 10 \%$ as an average of two to four measurements (each of 100-10000 pulses). All spectra (except the low-temperature phosphorus-31) were recorded at $298 \mathrm{~K}$.

Phosphorus-31 spectra (101.27 MHz) were obtained with a resolution of $7 \times 10^{-2} \mathrm{~Hz}$. Chemical shifts are reported relative to $85 \%$ external $\mathrm{H}_{3} \mathrm{PO}_{4}$; negative values refer to shielding.

Some of the $250.13-\mathrm{MHz}$ proton spectra were simulated in order to establish accurate values for the coupling constants and chemical shift parameters.

\section{Results and Discussion}

Addition of $\mathrm{LiX}\left(\mathrm{X}=\mathrm{F}, \mathrm{Cl}, \mathrm{Br}, \mathrm{ClO}_{4}\right)$ to solutions of 1-4 (Figure 1) in acetone reveals deshielding of the proton resonances in the ${ }^{1} \mathrm{H}$ NMR as a consequence of the complexation of the phosphoryl oxygen atom with the lithium cation, which results also in a deshielding of the phosphorus atom. These results are in accordance with former 3809 .

(12) Ramirez, F.; Marecek, J. F,; Ugi, J. J. Am. Chem. Soc. 1975, 97,
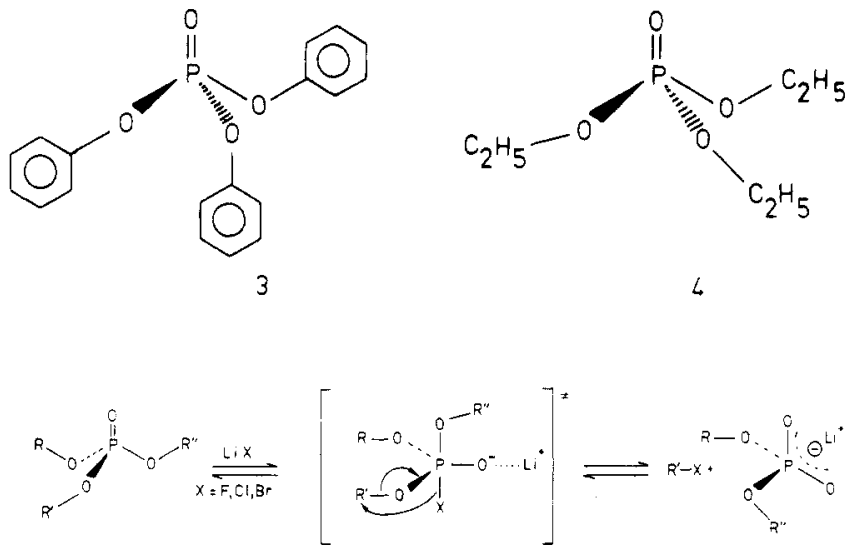

Flgure 2. $P(V)$ intermediate in the dealkylation reaction.

TABLE I: Kinetic Data of the System LiX (X = F, Cl, $\mathrm{Br}) / 2 /$ Methanol in Deuteriochloroform at $T=296 \mathrm{~K}^{a}$

\begin{tabular}{rrrrr}
\hline salt & $t_{1 / 2}, \mathrm{~min}$ & $r^{b} \AA$ & $10^{3} k, \mathrm{~s}^{-1}$ & $k_{\text {rel }}{ }^{c}$ \\
\hline $\mathrm{LiF}$ & 5.57 & & 2.15 & 1.00 \\
$\mathrm{LiCl}$ & 11.38 & 1.33 & 1.02 & 0.48 \\
$\mathrm{LiBr}$ & 31.81 & 1.81 & 0.88 & 0.40 \\
\multicolumn{1}{c}{ Concentrations are equimolar $(0.3 \mathrm{M}) . \quad{ }^{b}$ Anionic }
\end{tabular}

radius without solvation spheres. ${ }^{c} k_{\text {rel }}=k /\left(2.15 \times 10^{-3}\right)$.

work on salt-phosphate aggregates. ${ }^{11,13-16}$ The abovementioned adducts all disproportionate eventually to the corresponding dealkylated products in the case of $\mathrm{LiF}$, $\mathrm{LiCl}$, and $\mathrm{LiBr}$. The weakly nucleophilic $\mathrm{ClO}_{4}^{-}$ion is not capable of activating the dealkylation process. Our earlier NMR and kinetic experiments ${ }^{10,11}$ provided strong evidence for the involvement of a pentacoordinated phosphorus intermediate with only a moderate charge separation in the rate-determining step of the dealkylation reaction (Figure 2).

Kinetic Measurements. Addition of 1 equiv of methanol to a $0.5 \mathrm{M}$ solution of 2 in tetrahydrofuran (THF) results in a fast phosphorylation reaction. However, in the presence of 1 equiv of $\mathrm{LiBr}$, almost complete dealkylation is observed. ${ }^{11}$ In order to elucidate the observed decrease in the rate of phosphorylation we studied the model system $\mathrm{LiX}(\mathrm{X}=\mathrm{F}, \mathrm{Cl}, \mathrm{Br}) / 2 /$ methanol in equimolar ratio of the components $(0.3 \mathrm{M})$ in deuteriochloroform. To separate the reaction rates of the combined phosphorylation (path I, Figure 3) and dealkylation (path II, Figure 3) in the system, kinetic measurements in deuteriochloroform were performed on $2 /$ methanol (equimolar ratio, $0.3 \mathrm{M}$ ) and $2 / \mathrm{LiBr}$ (equimolar ratio, $0.3 \mathrm{M}$ ). Considering the poor solubility of $\mathrm{LiBr}$ in $\mathrm{CDCl}_{3}$ at $296 \mathrm{~K}\left(8 \times 10^{-3} \mathrm{~mol} / \mathrm{L}\right)$, the effective $\mathrm{LiBr}$ concentration in solution during the dealkylation process can be regarded as constant and the reaction becomes pseudo first order in phosphate with $k_{1}=$ $3.41 \times 10^{-3} \mathrm{~L} /(\mathrm{mol} \mathrm{s}) .{ }^{17}$ Earlier kinetic measurements of the dealkylation (path II) in the more polar acetone- $d_{6}$ revealed that the reaction was first order in phosphate and first order in $\mathrm{LiBr} .{ }^{10}$ In the case of phosphorylation (path

(13) Osipenko, N. G.; Petrov, E. S.; Ranneva, Yu. I.; Tsvetkov, E. N.; Shatenstein, A. I. Zh. Obshch. Khim. 1976, 47, 2172.

(14) Osipenko, N. G.; Petrov, E. S.; Tsvetkov, E. N.; Ranneva, Yu. I.; Shatenstein, A. I. Zh. Obshch. Khim. 1976, 46, 2647.

(15) Hong, A.; Lee, J.; Verkade, J. G. J. Am. Chem. Soc. 1976, 98, 6547.

(16) Breuer, E.; Bannet, D. M. Tetrahedron 1978, 24, 997.

(17) The reaction rate becomes $-\mathrm{d}(\mathrm{P}) / \mathrm{d} t=k_{2}(\mathrm{P})$ with $k_{2}=k_{1}(\mathrm{~B})$ in which $(P)$ is the concentration of phosphate $(\mathrm{mol} / \mathrm{L})$ and $(B)$ is the concentration of $\mathrm{LiBr}(\mathrm{mol} / \mathrm{L})$. This gives $\ln \left(P_{t=t} / P_{t=0}\right)=-k_{1}(\mathrm{~B}) t$ with an average $k_{1}=3.41 \times 10^{-3} \mathrm{~L} /(\mathrm{mol} \mathrm{s})$. (B) was estimated at $10^{-2} \mathrm{~mol} / \mathrm{L}$ (296 K). 

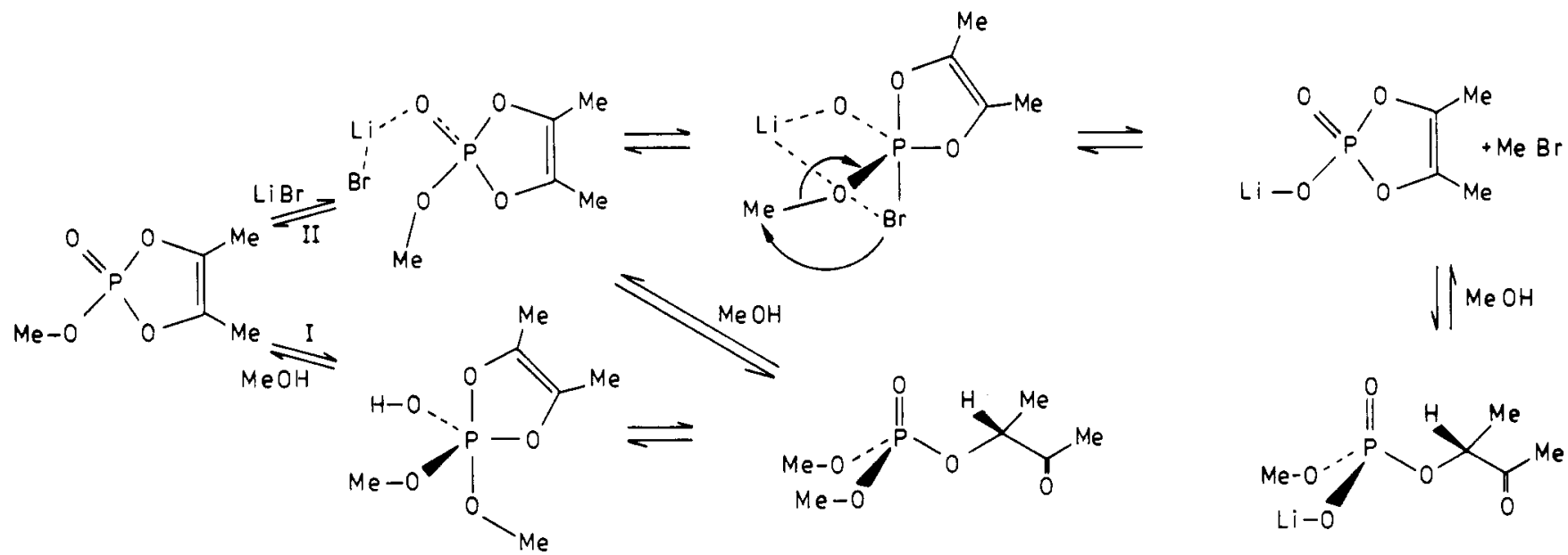

Figure 3. Kinetic pathways of the system $\mathrm{LIBr} / 2 /$ methanol in deuteriochloroform.

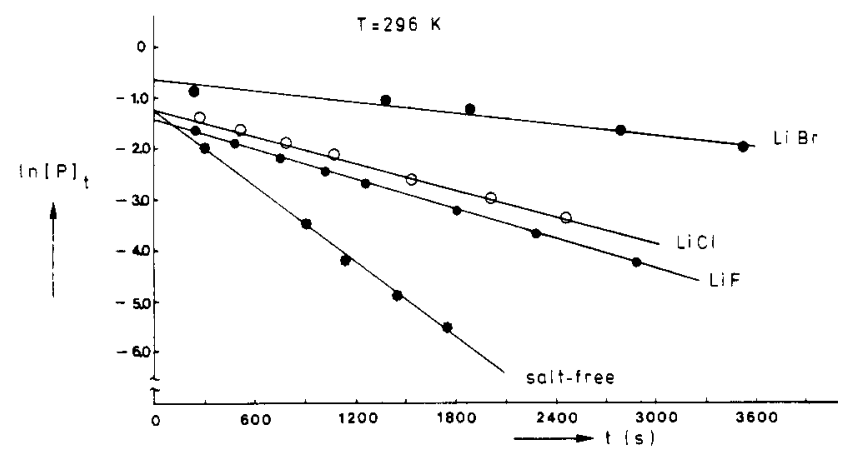

Flgure 4. Kinetic first-order plots of the system $L I X(X=F, C l, B r)$ / $2 /$ methanol in deuteriochloroform $(T=296 \mathrm{~K})$. The concentrations of the different compounds are equimolar $(0.3 \mathrm{M})$.

I) our kinetic measurements revealed that the reaction was first order in phosphate and of zero order in methanol with an average rate constant of $2.15 \times 10^{-3} \mathrm{~s}^{-1}$. As the phosphorylation proceeds much faster than the dealkylation, it is reasonable to neglect the latter path in case of the phosphate/salt/alcohol system. Therefore, the complex system (Figure 3) can be approximated by a total firstorder reaction in phosphate. ${ }^{18}$ The kinetic first-order plots of the phosphorylation (Figure 4) reveal that the reaction rate decreases in the order fluoride $>$ chloride $>$ bromide (Table I). The results show a relation between the reaction rate of the phosphorylation and the ionic radius of the different anions studied. The observed relation is not linear because of the different solvent reorientation properties of the halide ions involved. ${ }^{9}$ This creates unique solvation spheres for the various anions. As a result of their ordered solvation spheres, the halide ions, which appear as close-ion pairs ${ }^{9}$ in combination with the metal ion, are capable of screening the phosphorus atom against a nucleophilic attack of the methanol molecule (Figure 5). Consequently, the phosphorylation of methanol is retarded in comparison with the salt-free experiment. Most likely, attack of methanol proceeds by a displacement of the halogen atom followed by a fast intramolecular nucleophilic attack at the phosphorus atom. The kinetic data provide evidence for the proximity of the halide ion with regard to the phosphorus atom (viz., Figure 5).

${ }^{1} H N M R$. In order to improve our knowledge about the location of the $\mathrm{Li}^{+}$ion in the salt-phosphate complexes studied here, we took recourse to the paramagnetic $\mathrm{Eu}^{3+}$

(18) The measured rate constant for the phosphorylation is somewhat lower than the real value because of displacement of $\mathrm{CDCl}_{3}$ by methanol in the inner solvation shell of the lithium cation. As a consequence the amount of free methanol is slightly reduced.
TABLE II: Solvent and Salt Effects on the Chemical Shift Difference $\Delta \delta$ of the Methylene Protons of $1^{a}$

\begin{tabular}{|c|c|c|c|c|}
\hline \multirow{2}{*}{$\begin{array}{l}\text { close- } \\
\text { ion } \\
\text { pair }^{b}\end{array}$} & \multirow[b]{2}{*}{ salt } & \multirow[b]{2}{*}{ solvent } & \multicolumn{2}{|c|}{$\Delta \delta$} \\
\hline & & & solvent $^{c}$ & $\overline{\text { salt }^{d}}$ \\
\hline & & $\begin{array}{l}\left(\mathrm{CD}_{3}\right)_{2} \mathrm{SO} \\
\mathrm{CD}_{2} \mathrm{Cl}_{2} \\
\mathrm{CDCl}_{3}\end{array}$ & $\begin{array}{l}0 \\
0.048 \\
0.100\end{array}$ & \\
\hline yes & $\mathrm{LiClO}_{4}$ & $\mathrm{CD}_{3} \mathrm{NO}_{2}$ & 0 & 0.048 \\
\hline yes & $\mathrm{LiCl}$ (satd) & $\mathrm{CD}_{3} \mathrm{NO}_{2}$ & 0 & 0.060 \\
\hline yes & $\mathrm{LiCl}$ (satd) & $\left(\mathrm{CD}_{3}\right)_{2} \mathrm{CO}$ & 0.01 & 0.050 \\
\hline yes & $\mathrm{LiBr}$ (1 equiv) & $\left(\mathrm{CD}_{3}\right)_{2} \mathrm{CO}$ & 0.01 & 0.286 \\
\hline yes & $\mathrm{LiBr}$ (satd) & $\mathrm{C}_{6} \mathrm{D}_{6}$ & $0.176^{e}$ & 0.504 \\
\hline no & $\mathrm{LiClO}_{4}$ & $\mathrm{SO}_{2} \mathrm{liq}$ & 0 & 0 \\
\hline no & $\mathrm{LiBr}$ (1 equiv) & $\mathrm{SO}_{2} \mathrm{liq}$ & 0 & 0 \\
\hline no & $\mathrm{LiBr}$ & $\left(\mathrm{CD}_{3}\right)_{2} \mathrm{SO}$ & $\approx 0$ & 0 \\
\hline no & $\mathrm{AlCl}_{3}$ & $\left(\mathrm{CD}_{3}\right)_{2} \mathrm{CO}$ & 0.010 & 0 \\
\hline no & $\mathrm{LiBr} / \mathrm{kryp}$ tofix & $\left(\mathrm{CD}_{3}\right)_{2} \mathrm{CO}$ & 0.010 & 0 \\
\hline
\end{tabular}

${ }^{a} 250.13-\mathrm{MHz}^{1} \mathrm{H}$ NMR $(T=298 \mathrm{~K}) .{ }^{b}$ According to Popov $^{8}$ and Weingärtner. ${ }^{c}{ }^{c}$ Solvent-induced differential shielding. ${ }^{d} \Delta \delta$ (salt): measured total effect, containing contributions from both solvent and ion pairs. $e$ This large effect can be explained by aromatic-solvent-induced shift (ASIS) which is known for phenyl fragments.

$f$ Kryptofix $221 / \mathrm{LiBr}$ in $1 / 1$ mole ratio.

ion in combination with 1. Addition of $\mathrm{Eu}(\text { fod })_{3}{ }^{19}$ to a solution of 1 in $\mathrm{CDCl}_{3}$ reveals deshielding for all the proton resonances in the NMR spectrum due to phosphoryl oxygen complexation by the paramagnetic $\mathrm{Eu}^{3+}$ ion (Figure 6). The shift of the tertiary isopropoxy proton (4) shows a high concentration dependence. Obviously, the $\mathrm{Eu}^{3+}$ ion is situated in the proximity of this proton. This confirms our earlier observed complexation of the phosphoryl oxygen atom by the $\mathrm{Li}^{+}$ion. ${ }^{11}$ Moreover, the asymmetric ring in the structure causes, via preferred orientation of the $\mathrm{Eu}(\mathrm{fod})_{3}$ complex, increased shift differences of the isopropoxy methyl groups at higher $\mathrm{Eu}$ (fod) ${ }_{3}$ concentrations (viz., two resonances (11). The asymmetric location of the $\mathrm{Eu}^{3+}$ ion with respect to the ring methylene protons 3 and $3^{\prime}$ causes a different deshielding for both protions. From molecular model building studies one would expect intrinsically inequivalent resonances of the methylene protons. Indeed the $250.13-\mathrm{MHz}^{1} \mathrm{H}$ NMR spectrum of 1 in acetone- $d_{6}$ revealed inequivalent resonances $(\Delta \delta=2.5 \mathrm{~Hz}$; $0.01 \mathrm{ppm}$; Figure 7). This value appeared to be solvent dependent and should therefore be ascribed to solventinduced differential shielding effects (Table II). From

(19) $\mathrm{Eu}(\mathrm{fod})_{3}$ : tris $(6,6,7,7,8,8,8$-heptafluoro-2,2-dimethyl-3,5-octanedionato)europium. 

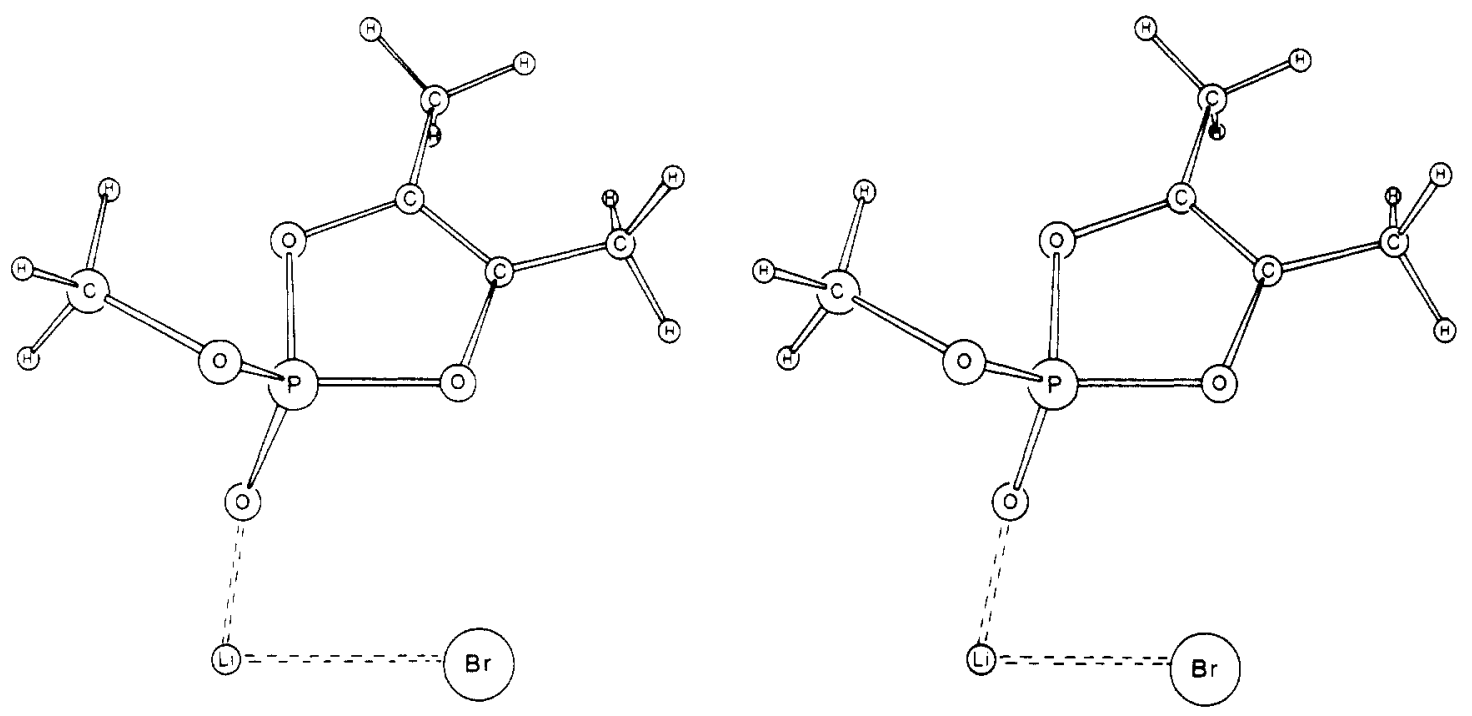

Figure 5. Stereoscopic drawing of the $\mathrm{LiBr}-2$ aggregate. The closest $\mathrm{P}-\mathrm{Br}$ distance in the complex was calculated to be $4.0 \AA$. The different radil used for scaling do not represent solvation.

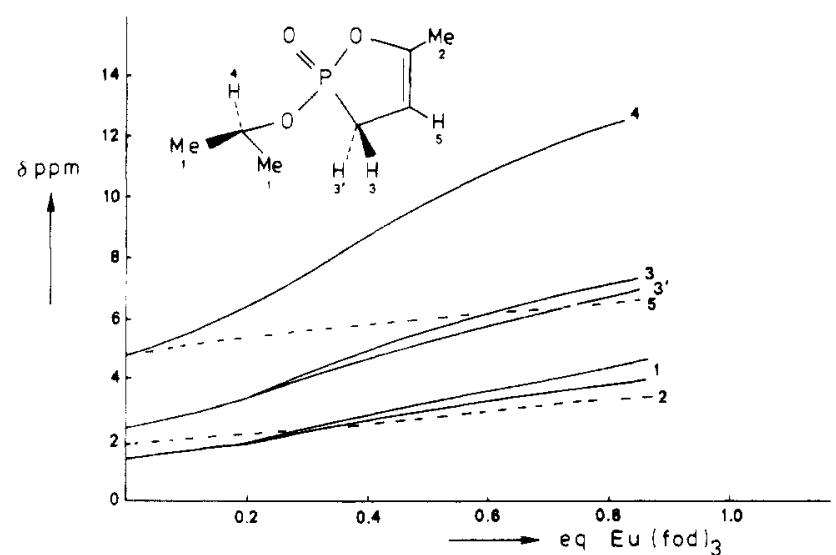

Figure 6. $60-\mathrm{MHz}{ }^{1} \mathrm{H}$ NMR results of 1 in $\mathrm{CDCl}_{3}$ with different concentrations of Eu(fod) $)_{3} . \quad \delta$ in ppm vs. $\mathrm{Me}_{4} \mathrm{Si}(T=298 \mathrm{~K})$.

earlier research in this laboratory ${ }^{10,11}$ it was established that the shift difference between the methylene protons was dependent on the anion, on the cation, and also on the bulkiness of the exocyclic alkoxy ligand. Comparison with the literature on solutions of alkali halides in organic solvents ${ }^{9}$ revealed that a large $\Delta \delta$ is observed in those cases where the ions of the salts form close pairs and in which one or both ions are surrounded by partially oriented solvent molecules. Therefore, the observed $\Delta \delta$ in the case of close-ion pairs can best be explained by reorientation effects of the solvent structure near the close-ion pair and concomitant electric field effects.

From Table II it is evident that there is no salt-induced $\Delta \delta$ of the methylene protons in the case of fully complexed or solvated cations and anions. Hence, only possible solvent-induced differential shielding can be measured ( $\Delta \delta$ (solvent), viz., Table II). In the case of $\mathrm{SO}_{2}$ we have fully solvated halide anions which prevent salt-induced $\Delta \delta$ of the protons. In the case of $\mathrm{AlCl}_{3}$ we have a Lewis acid which complexes halide anions. ${ }^{11}$

${ }^{7} \mathrm{Li}$ NMR measurements of a 1:2 mixture of kryptofix $221^{20}$ and $\mathrm{LiBr}$ in acetone reveal two resonances at $\delta 2.43$ and -0.11 which can be attributed to the $\mathrm{LiBr}$ in solution and the fully complexed kryptofix $221 \cdot \mathrm{Li}^{+}$, respectively. In a $1: 1$ mixture there is no free $\mathrm{LiBr}$ in solution. As a result there is no salt-induced $\Delta \delta$.

(20) Kryptofix 221: 4,7,13,16,21-pentaoxa-1,10-diazabicyclo[8.8.5]tricosane.

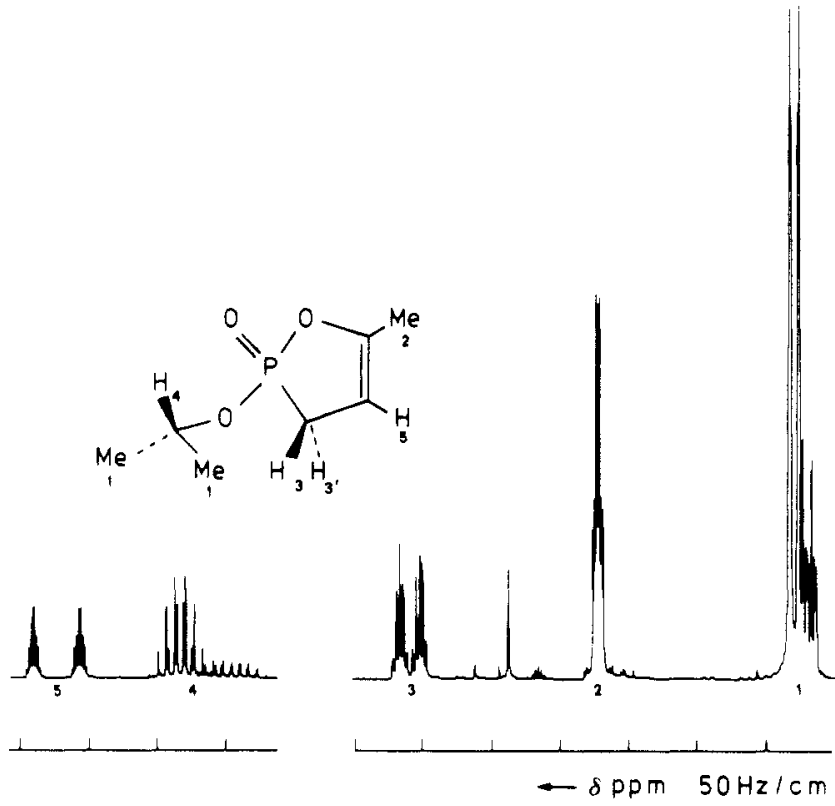

Flgure 7. 250.13-MHz ${ }^{1} \mathrm{H}$ NMR spectrum of 1 in acetone- $d_{6} . \delta$ in ppm vs. $\mathrm{Me}_{4} \mathrm{Si}(T=298 \mathrm{~K})$.

Formation of a covalent bond between the $\mathrm{Li}^{+}$ion and the phosphoryl oxygen atom would lead to a positively charged phosphorus atom. In order to investigate a possible change in net atomic charge on the phosphorus atom upon addition of lithium salt the accurate values of the ${ }^{2} J_{\mathrm{HH}}$ geminal coupling constants ${ }^{21}$ had to be determined via computer simulation of the $250.13-\mathrm{MHz}^{1} \mathrm{H}$ NMR spectra of 1 in acetone- $d_{6}$, with 1 equiv of $\mathrm{LiBr}$ in acetone- $d_{6}$ and in hexadeuteriobenzene (Figures 8-10). The results are summarized in Table III. From this table it is evident that the difference in ${ }^{2} J_{\mathrm{HH}}$ between acetone- $d_{6}$ and acetone- $d_{6}$ with 1 equiv of $\mathrm{LiBr}$ is $0.34 \mathrm{~Hz}$. This implies a negligible change in the net atomic charge on the phosphorus atom. Moreover, this conclusion is consistent with the fact that we observed only small (approximately $1 \mathrm{ppm}){ }^{31} \mathrm{P}$ chemical shift differences upon addition of salt.

${ }^{31} P N M R$. Earlier work in this laboratory concerning the kinetics of dealkylation reactions in organophosphorus

(21) Substitution of an electronegative atom in a $\beta$-position leads to a negative change in ${ }^{2} J_{\mathrm{HH}}$. See: "Proton and Carbon-13 NMR Spectroscopy. An Integrated Approach"; Abraham, R. J., Loftus, P., Eds.; Heyden: London, 1978; p 47. 

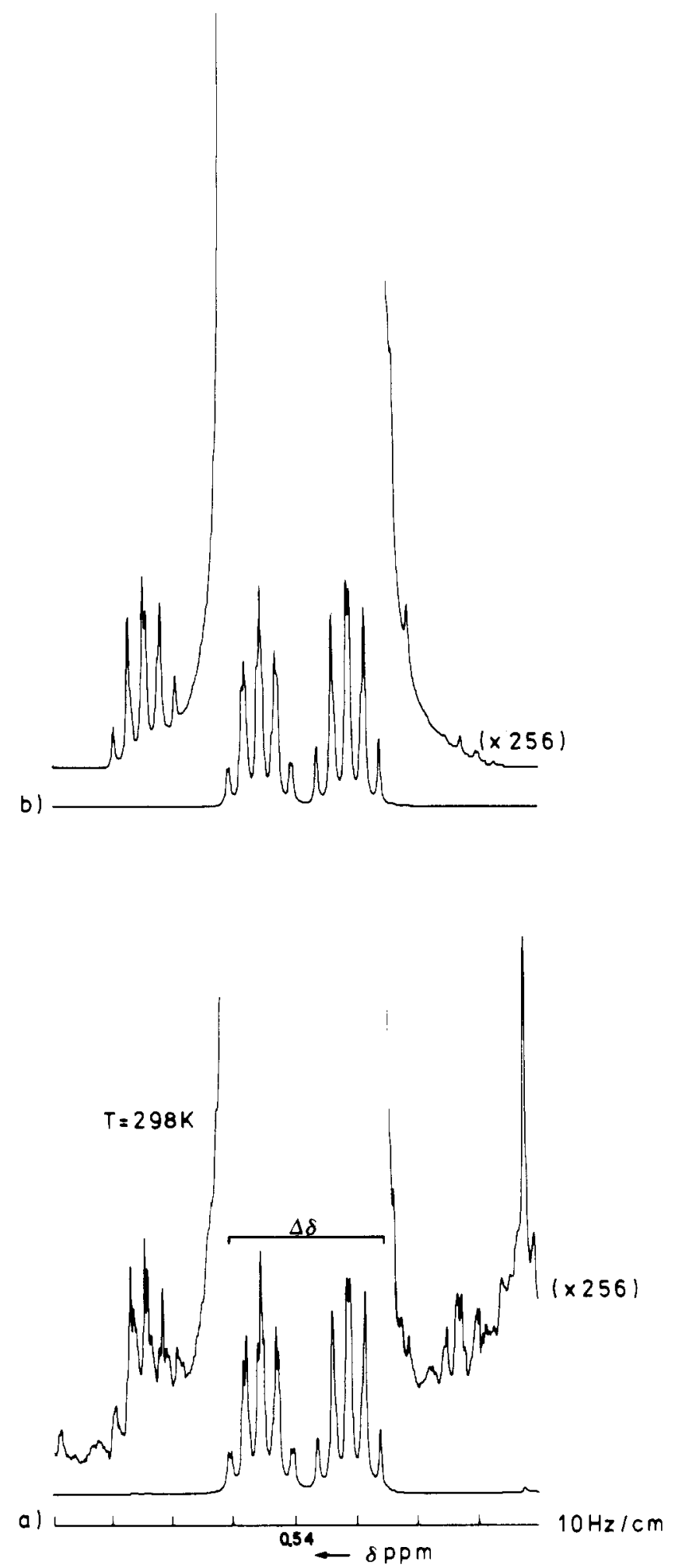

Figure 8. Recorded (a) and simulated (b) 250.13-MHz ${ }^{1} \mathrm{H}$ NMR spectrum of the methylene protons of 1 in acetone- $d_{8}$. Notice the resemblance of the fine structure in the low-field domain (nearty forbidden transitions).

compounds ${ }^{10,11}$ strongly points to pentacoordinated intermediate structures. We decided to investigate possible intermediate structures by means of low-temperature ${ }^{31} \mathrm{P}$ NMR techniques.

Recent work of Granoth et al. ${ }^{22}$ showed structures intermediate between halophosphoranes (pentacoordinated structure) and phosphonium halides with covalent phosphorus-halogen bonds, which have a very large degree of

(22) Granoth, I.; Martin, J. C. J. Am. Chem. Soc. 1981, 103, 2711.

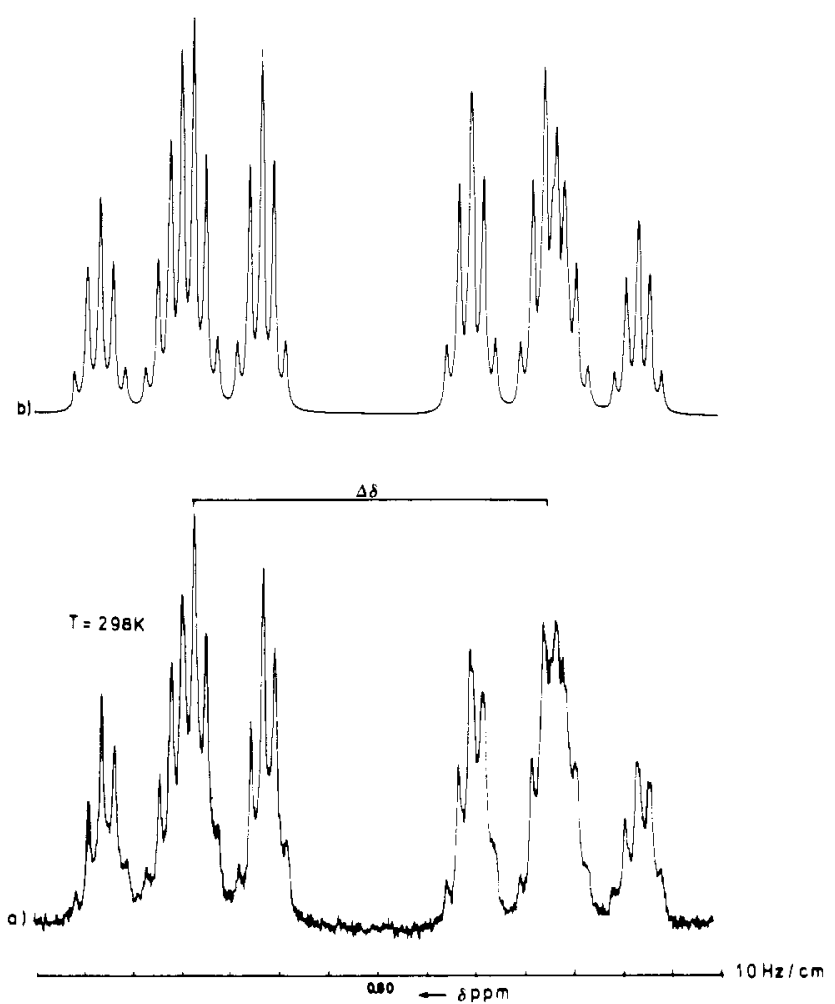

Figure 9. Recorded (a) and simulated (b) 250.13-MHz ${ }^{1} \mathrm{H}$ NMR spectrum of the methylene protons of 1 with 1 equiv of $L i B r$ in acetone-d $d_{6}$.

TABLE III : Indirect Coupling Constants $(J)$ and Chemical Shift Values $(W)$ via Computer-Simulated 250.13-MHz ${ }^{1} \mathrm{H}$ NMR Spectra of 1<smiles></smiles>

\begin{tabular}{|c|c|c|c|c|}
\hline & $W,^{a}$ ppm & \multicolumn{3}{|c|}{$J, \mathrm{~Hz}$} \\
\hline $\begin{array}{l}W(1) \\
W(2) \\
W(3) \\
W(4) \\
W(5)\end{array}$ & $\begin{array}{l}\text { Aceton } \\
0.538 \\
0.548 \\
3.201 \\
0\end{array}$ & $\begin{array}{cr}-d_{6}, \text { Rms } & \text { Error }= \\
J_{12} & 12.64 \\
J_{13} & 15.74 \\
J_{14} & 33.61 \\
J_{15} & 0.80 \\
J_{23} & -18.67\end{array}$ & $\begin{array}{l}042 \\
J_{24} \\
J_{25} \\
J_{34} \\
J_{35} \\
J_{45}\end{array}$ & $\begin{array}{l}2.75 \\
2.55 \\
3.08 \\
2.28 \\
1.44\end{array}$ \\
\hline $\begin{array}{l}W(1) \\
W(2) \\
W(3) \\
W(4) \\
W(5)\end{array}$ & $\begin{array}{l}\text { Benzen } \\
0.681 \\
0.503 \\
2.917 \\
0\end{array}$ & $\begin{array}{cr}d_{6}, \text { Rms } & \text { Error }= \\
J_{12} & 13.46 \\
J_{13} & 15.24 \\
J_{14} & 33.54 \\
J_{15} & 0.85 \\
J_{23} & -18.41\end{array}$ & $\begin{array}{l}116 \\
J_{24} \\
J_{25} \\
J_{34} \\
J_{35} \\
J_{45}\end{array}$ & $\begin{array}{l}2.72 \\
2.49 \\
3.03 \\
2.30 \\
1.45\end{array}$ \\
\hline $\begin{array}{l}\text { Aceton } \\
W(1) \\
W(2) \\
W(3) \\
W(4) \\
W(5)\end{array}$ & $\begin{array}{l}d_{6} / \operatorname{LiBr} 1 \\
0.551 \\
0.656 \\
3.297 \\
0\end{array}$ & 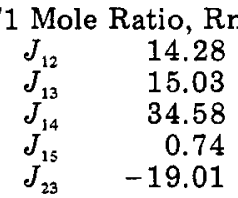 & $\begin{array}{l}\text { Erro } \\
J_{24} \\
J_{25} \\
J_{34} \\
J_{35} \\
J_{45}\end{array}$ & $\begin{array}{l}0.167 \\
2.69 \\
2.48 \\
2.74 \\
2.36 \\
1.43\end{array}$ \\
\hline
\end{tabular}

${ }^{a} W(2)$ and $W(3)$ may be interchanged.

ionic character. ${ }^{31} \mathrm{P}$ chemical shifts were measured near +40 ppm which points to phosphonium structures. Granoth took recourse to electric field induced contributions to explain the deshielding of one of the aromatic protons $\mathrm{H}_{0}$ (Figure 11). Over such small distances relatively large uncertainties exist in the use of the formalism, both in order of magnitude and in direction. ${ }^{23}$ Moreover, an ion 


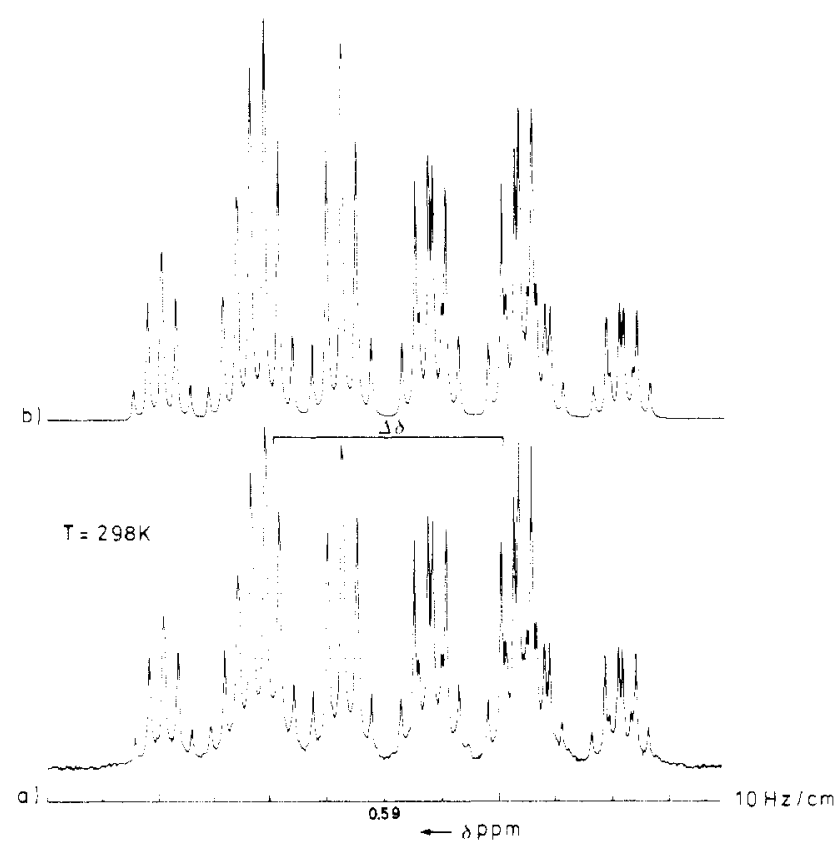

Figure 10. Recorded (a) and simulated (b) 250.13-MHz ${ }^{1} \mathrm{H}$ NMR spectrum of the methylene protons of 1 in $C_{6} D_{6}$.

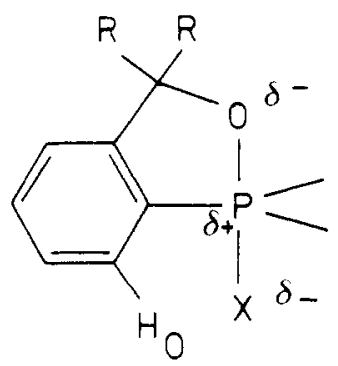

Flgure 11. Deshieiding of the $H_{0}$ proton caused by the electric field induced contributions of $\mathrm{P}-\mathrm{X}$ dipole.

pair suitably oriented with respect to the $\mathrm{C}-\mathrm{H}_{0}$ bond could very well have the same effect, i.e., a covalent or ionic $\mathrm{P}-\mathrm{X}$ bond $(\mathrm{X}=$ halogen $)$ is not necessary in order to explain deshielding of the $\mathrm{H}_{0}$ proton. The orientation of the halide anion with respect to the phosphorus atom is probably determined largely by steric factors.

We investigated whether in the salt-phosphate aggregates studied here a stable pentacoordinated structure could be trapped at low temperature. In the case of the bromine anion, 2 revealed the highest rate of dealkylation and thus a concomitant low activation energy $\left(E_{\mathrm{a}} \simeq 12.5\right.$ $\mathrm{kJ} / \mathrm{mol}$ ) to form the pentacoordinated intermediate state. ${ }^{11}$ Therefore, low-temperature 101.27-MHz ${ }^{31} \mathrm{P}$ NMR spectra of 2 in tetrahydrofuran- $d_{8}$ were recorded. The low dielectric constant of THF $(\epsilon=7.4 ; T=298 \mathrm{~K})$ precludes any ion-pair dissociation thus supporting the generation of a pentacoordinated intermediate. Covalent character of the phosphorus-fluoride interaction should be accurately measurable because of the large ${ }^{1} J_{\mathrm{PF}} \simeq 1000 \mathrm{~Hz}^{24}$ Addition of 1 equiv of $\mathrm{LiF}$ at $213 \mathrm{~K}$ to a solution of $2(0.3$ M) in THF- $d_{8}$ revealed a line broadening of $1.75 \mathrm{~Hz}$ and an upfield shift of $0.40 \mathrm{ppm}$. No doublet in the ${ }^{31} \mathrm{P}$ resonance could be resolved in the temperature region 213-298 K. The same result was obtained in case of $\mathrm{NaF}$.

Very recently Richman et al. ${ }^{25}$ published the ${ }^{31} \mathrm{P}$ and ${ }^{19} \mathrm{~F}$ NMR results of cyclenfluorophosphoranes and demon-

(23) van Dommelen, M. E.; de Haan, J. W.; Buck, H. M. Org. Magn. Reson. 1980, 14, 497.

(24) Crutchfield, M. M.; et al. "Topics in Phosphorus Chemistry"; Interscience: New York, 1967; Vol. 5, pp 280-2.
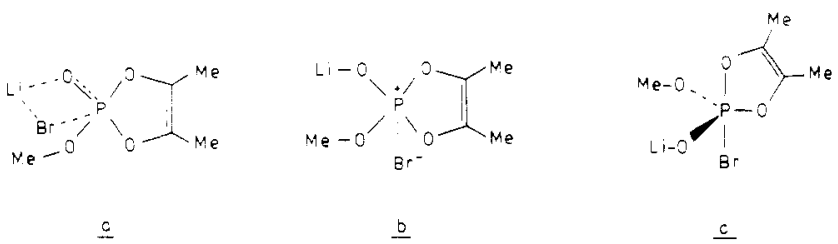

Figure 12. Different geometries of the $\mathrm{LiBr} / 2$ complex: (a) closeion-pair structure, (b) phosphonium structure, (c) pentacoordinate structure.

TABLE IV: 97.21-MHz Lithium-7 Chemical Shifts (ppm) of 1/1 Mole Ratio $\mathrm{LiBr} /$ Model Compound Aggregates in Acetone at $T=298 \mathrm{~K}^{a}$

\begin{tabular}{|c|c|c|c|c|c|c|c|}
\hline \multicolumn{2}{|c|}{$\mathrm{LiBr} / 1$} & \multicolumn{2}{|c|}{$\mathrm{LiBr} / 3$} & \multicolumn{2}{|c|}{$\mathrm{LiBr} / 4$} & \multicolumn{2}{|c|}{$\mathrm{LiBr}$} \\
\hline$M^{b}$ & $\overline{\delta\left({ }^{7} \mathrm{Li}\right)^{c}}$ & $M$ & $\delta\left({ }^{7} \mathrm{Li}\right)$ & $\vec{M}$ & $\delta\left({ }^{7} \mathrm{Li}\right)$ & $M$ & $\delta\left({ }^{7} \mathrm{Li}\right)$ \\
\hline 0.11 & 2.23 & 0.13 & 2.41 & 0.11 & 2.15 & 0.09 & 2.50 \\
\hline 0.31 & 2.04 & 0.25 & 2.32 & 0.26 & 2.03 & 0.24 & 2.48 \\
\hline $0.4^{\prime} 7$ & 1.98 & 0.50 & 2.17 & 0.49 & 1.89 & 0.53 & 2.47 \\
\hline 0.94 & 1.81 & 1.00 & 1.95 & 0.98 & 1.78 & 0.94 & 2.36 \\
\hline
\end{tabular}

strated a clear distinction between covalent and ionic structures. In the ionic structures, no ${ }^{1} J_{\mathrm{PF}}$ was observed whereas in the pentacoordinated structures couplings of $800-900 \mathrm{~Hz}$ were measured. Our earlier work gave evidence for generation of pentacoordinated intermediate structures during dealkylation reactions. We argue that, in the salt aggregates studied here, it is possible with NMR techniques to measure the change in solvation but not pentacoordinated intermediate structures with a lifetime short on the NMR time scale. ${ }^{26}$ In addition, different intermediate geometries of 2 with 1 equiv of $\mathrm{LiBr}$ were calculated by the CNDO/2 method. ${ }^{27}$ Optimalization of the different structures a-c (Figure 12) revealed a decreasing stability in the order $a>b>c$. The kinetic data on dealkylation reactions point to pentacoordinate intermediate structures. Combined with our calculations this implies a short-living structure of type $c$ as a result of the interaction of the d orbitals of the phosphorus atom with the unpaired electron pairs of the bromine anion. Structure a seems the most stable, NMR-observed configuration.

${ }^{7} \mathrm{Li},{ }^{35} \mathrm{Cl}$, and ${ }^{81} \mathrm{Br} N M R$. The results of our ${ }^{1} \mathrm{H}$ and ${ }^{31} \mathrm{P}$ NMR measurements prompted us to study also the deportment of the $\mathrm{Li}^{+}$ions in the salt-phosphate aggregates in acetone by means of ${ }^{7} \mathrm{Li} \mathrm{NMR}$. With respect to the anionic behavior in the salt-phosphate complexes, we took recourse to ${ }^{35} \mathrm{Cl}$ and ${ }^{81} \mathrm{Br}$ NMR techniques. The data of the ${ }^{7} \mathrm{Li},{ }^{35} \mathrm{Cl}$, and ${ }^{81} \mathrm{Br}$ studies are shown in Figures $13-16$ and in Tables IV-VIII.

The properties of ${ }^{7} \mathrm{Li}$ nuclei are quite favorable for NMR studies. The resonance lines of the $\mathrm{Li}^{+}$ion in solutions are exceptionally narrow $\left(W_{1 / 2} \approx 2 \mathrm{~Hz}\right)^{28}$ and chemical shifts (against $4.0 \mathrm{M}$ aqueous perchlorate solution) can be measured with considerable accuracy. The results available for chlorine and bromine NMR in nonaqueous solvents are limited. Halide ion quadrupole relaxation rates have been reported for methanol, $, 92,30$ dimethyl sulf-

(25) Richman, J. E.; Flay, R. B. J. Am. Chem. Soc. 1981, 103, 5265.

(26) In our attempt to extend the lifetime of the intermediate structure, we prepared $2-(1,1,1,3,3,3$-hexafluoro) isopropoxy-2-oxo-4,5-dimethyl-1,3,2-dioxaphosphol-4-ene. Upon addition of 1 equiv of $\mathrm{LiX}$ (X $=\mathrm{F}, \mathrm{Cl}, \mathrm{Br}$ ) this compound showed no dealkylation because of the strongly reduced tendency for $\mathrm{P}=0$ bond formation from this ligand. (27) Rinaldi, D. Comput. Chem. 1976, 1, 109. Program 290, QCPE, Indiana University, Bloomington, IN.

(28) $W_{1 / 2}=$ width of a resonance line at half-height.

(29) Linḋman, B.; Forsên, S.; Forslind, E. J. Phys. Chem. 1968, 72, 2805 . 
TABLE V: Limiting Values at $T=298 \mathrm{~K}$ for Infinite Dilution of Lithium-7 Chemical Shifts (ppm) and Bromine-81 Line Widths $(\mathrm{kHz})$ of $1 / 1$ Mole Ratio Complexes of Model Compound/Salt in Acetone

\begin{tabular}{ccc}
\hline & \multicolumn{2}{c}{ limiting values } \\
\cline { 2 - 3 } compd & $\delta\left({ }^{7} \mathrm{Li}\right)^{a}$ & $W_{1 / 2}\left({ }^{81} \mathrm{Br}\right)^{b}$ \\
\hline $\mathrm{LiBr} \mathrm{sec}$ & 2.53 & 6.3 \\
$1 / \mathrm{LiBr}$ & 2.36 & 8.5 \\
$3 / \mathrm{LiBr}$ & 2.53 & 6.6 \\
$4 / \mathrm{LiBr}$ & 2.26 & 7.2
\end{tabular}

${ }^{a}$ Estimated accuracy, $2 \times 10^{-2} \mathrm{ppm}$; chemical shift in ppm vs. $4.0 \mathrm{M}$ aqueous $\mathrm{LiClO}_{4}$ solution. ${ }^{b}$ Estimated accuracy, $0.5 \mathrm{kHz}$.

oxide, ${ }^{9,29}$ nitromethane, ${ }^{31}$ formic acid, ${ }^{9} \mathrm{~N}$-methylformamide, ${ }^{9}$ dimethylformamide, ${ }^{9}$ acetonitrile, ${ }^{9}$ and acetone ${ }^{9}$ and for mixtures of acetonitrile, ${ }^{32}$ methanol, ${ }^{30,33}$ and acetone $\mathrm{e}^{33}$ with water.

From Table IV it is evident that the ${ }^{7} \mathrm{Li}$ chemical shifts of lithium bromide are concentration dependent. This concentration dependence can be attributed to the formation of contact ion pairs, i.e., to cases where the anion directly replaces a solvent molecule or molecules in the inner solvation shell of the cation. ${ }^{8}$ It has been previously observed $^{34,35}$ that the contact ion pair equilibrium strongly depends on the donor ability of the solvent molecule as well as on the bulk dielectric constant $\epsilon$ of the medium. Acetone has a dielectric constant of 20.7 ( $298 \mathrm{~K})$, its donor ability is reasonably high, and on Gutmann's scale ${ }^{36}$ its donor number is 17.0. Contact ion pair formation in acetone occurs likewise in the case of lithium chloride (Table VII). We notice, that the ${ }^{7} \mathrm{Li}$ chemical shifts are clearly dependent on the counterion $\left(\mathrm{Cl}^{-}, \mathrm{Br}^{-}, \mathrm{ClO}_{4}^{-}\right)$and on the concentration. The ${ }^{7} \mathrm{Li}$ chemical shift values agree reasonably well with those reported by Maciel et al. ${ }^{37}$ and by Akitt and Downs. ${ }^{38}$ From Table IV we see that addition of 1 equiv of the phosphoryl compounds 1,3 , or 4 to the lithium bromide solution results in shielding of the ${ }^{7} \mathrm{Li}$ nucleus. This shielding occurs as a result of replacement of at least one of the four carbonyl groups in the inner solvation shell of the lithium ion by a phosphoryl group. ${ }^{39}$ Addition of small amounts of water results in an analogous replacement by water. Limiting ${ }^{7} \mathrm{Li}$ chemical shift values for infinite dilution (extrapolation from data in Table IV) are listed in Table V. From our CNDO/2 geometry optimalizations of the model compounds 1 and 4 there seems to be a correlation between the dipole moment of the phosphate/phosphonate (8.23 and 8.83 D for 1 and 4, respectively) and the value of the limiting ${ }^{7} \mathrm{Li}$ chemical shift. A larger dipole moment results in a larger shielding of the ${ }^{7} \mathrm{Li}$ nucleus. Compound 3 shows a different deportment (dipole, $13.05 \mathrm{D}$ ). The results of the ${ }^{81} \mathrm{Br}$ line width measurements of the $1: 1 \mathrm{LiBr}$-model compound complexes are plotted in Figure 13. There is considerable

(30) Hall, C.; Haller, G. L.; Richards, R. E. Mol. Phys. 1969, 16, 377. (31) Gentzler, R. E.; Stengle, T. R.; Langford, C. H. Chem. Commun. $1970,1257$.

(32) Stengle, T. R.; Pan, Y.C. E.; Langford, C. H. J. Am. Chem. Soc. 1972, 94, 9037 .

(33) Richards, R. E.; Yorke, B. A. Mol. Phys. 1963, 6, 289

(34) Greenberg, M. S.; Bodner, R. L.; Popov, A. I. J. Phys. Chem. 1973, 77,2449 and references listed therein.

(35) Mayer, U.; Gutmann, V. Struct. Bonding (Berlin) 1972, 12, 113. (36) Gutmann, V. In "Co-ordination Chemistry in Nonaqueous Solvents"; Springer-Verlag: Vienna, 1968; p 19.

(37) Maciel, G. E.; Hancock, J. K.; Lafferty, L. F.; Mueller, P. A Musker, W. K. Inorg. Chem. 1966, 5, 554.

(38) Akitt, J. W.; Downs, A. J. In "The Alkali Metals Symposium”; The Chemical Society: London, 1967; p 199.

(39) Baum, R. G.; Popov, A. I. J. Solution Chem. 1975, 4, 441.

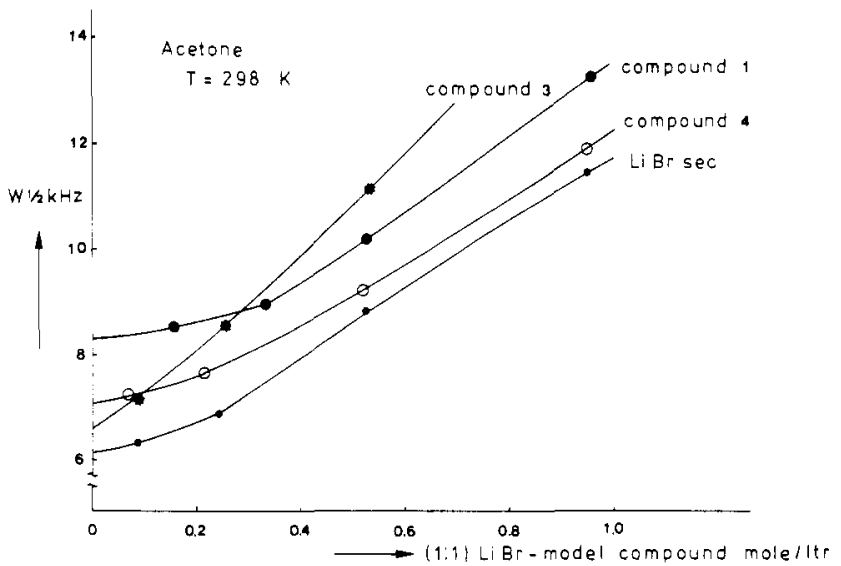

Figure 13. $67.55-\mathrm{MHz}$ bromine-81 line widths $\left(W_{1 / 2}\right)$ of $(1: 1) \mathrm{LiBr}-$ model compound aggregates in acetone.

broadening of the ${ }^{81} \mathrm{Br}$ resonance with increasing concentration of the complexes in acetone. The observed concentration-dependent broadening of the ${ }^{81} \mathrm{Br}$ resonance is indicative of contact ion pair formation because of asymmetrical solvation of the bromine anion, caused by a contribution of the ( $\mathrm{Li}-\mathrm{O}-\mathrm{P})$ fragment, thus enhancing the electrical anisotropy around the ${ }^{81} \mathrm{Br}$ nucleus. This results in an increase in line width with increasing salt concentration. The contribution of the $(\mathrm{Li}-\mathrm{O}-\mathrm{P})$ fragment to the electrical anisotropy of the ellipsoidal ${ }^{81} \mathrm{Br}$ nucleus can also account for the difference in limiting values of the ${ }^{81} \mathrm{Br}$ line widths in the 1:1 complexes and in $\mathrm{LiBr}$ (viz., Table V). Table IV and Figure 13 reveal that no distinction can be made between the cyclic and the acyclic model compounds. The different behavior of 3 (Figure 13) might be explained by a larger distortion of the solvent structure due to a relatively high molecular weight $\left(M_{\mathrm{v}}=326\right.$ vs. 176 and 182 for 1 and 4, respectively) and by the relatively high molecular dipole (our CNDO/2 calculations: $13.05 \mathrm{D}$ ). The distortion of the solvent structure in the case of 3 is reflected in an extra line width of the ${ }^{81} \mathrm{Br}$ nucleus with increasing phosphate concentration.

Tables VI-VIII show the influence of increasing model compound concentration on the ${ }^{7} \mathrm{Li}$ chemical shift with constant concentration of lithium bromide, lithium chloride, and lithium perchlorate, respectively. These tables reveal that the ${ }^{7} \mathrm{Li}$ chemical shift is dependent on the sort of phosphate molecule involved but independent of the nature of the anion $\left(\mathrm{Cl}^{-} \mathrm{vs} . \mathrm{Br}^{-}\right)$. The ${ }^{7} \mathrm{Li}$ measurements reveal a fast equilibrium reaction in the case of the saltphosphate aggregates. Addition of extra lithium salt and dilution to a former measured concentration results in exactly the same ${ }^{7} \mathrm{Li}$ chemical shift. The concentration dependence of the ${ }^{7} \mathrm{Li}$ chemical shift increases with increasing salt concentration.

Addition of water results in shielding of the ${ }^{7} \mathrm{Li}$ nucleus analogous to the results of Popov. ${ }^{8}$ This shielding increases with decreasing salt concentration and is independent of the anion $\left(\mathrm{Cl}^{-}\right.$vs. $\left.\mathrm{Br}^{-}\right)$. Recent ab initio studies indicate that in the $\mathrm{Li}^{+} \ldots \mathrm{H}_{2} \mathrm{PO}_{4}^{-}$complex hydration of the $\mathrm{Li}^{+}$ion does not significantly alter the extent of covalency of the metal-phosphate bond, although it weakens the direct complex formation by partial neutralization of the cation. The concentration-dependent chemical shift differences in the case of the ${ }^{7} \mathrm{Li}$ nucleus are in the same range as observed for 1:1 complexes (Table IV). Therefore, in spite of the large excess of model compound, it can be concluded that there is a high preference to replace only one of the four carbonyl groups in the inner solvation shell of the lithium cation by a phosphoryl fragment and exclusively 1:1 complexes salt-phosphate have to be considered. In 
TABLE VI: 97.21-MHz Lithium-7 Chemical Shifts (ppm) of Salt/Phosphate Aggregates in Acetone at $T=298 \mathrm{~K}^{a}$

\begin{tabular}{|c|c|c|c|c|c|c|c|c|c|c|c|}
\hline \multicolumn{4}{|c|}{1} & \multicolumn{4}{|c|}{3} & \multicolumn{4}{|c|}{4} \\
\hline$M^{b}$ & $\delta\left({ }^{7} \mathrm{Li}\right)$ & $M^{c}$ & $\delta\left({ }^{7} \mathrm{Li}\right)$ & $M^{d}$ & $\delta\left({ }^{7} \mathrm{Li}\right)$ & $M^{e}$ & $\delta\left({ }^{7} \mathrm{Li}\right)$ & $M^{f}$ & $\delta\left({ }^{7} \mathrm{Li}\right)$ & $M^{g}$ & $\delta\left({ }^{7} \mathrm{Li}\right)$ \\
\hline 0 & 2.51 & 0 & 2.42 & 0 & 2.50 & 0 & 2.46 & 0 & 2.50 & 0 & 2.44 \\
\hline 0.09 & 2.23 & 0.12 & 2.30 & 0.13 & 2.39 & 0.14 & 2.36 & 0.15 & 1.73 & 0.16 & 2.20 \\
\hline 0.26 & 1.84 & 0.44 & 2.01 & 0.27 & 2.28 & 0.39 & 2.21 & 0.54 & 1.20 & 0.49 & 1.78 \\
\hline 0.65 & 1.33 & 0.86 & 1.66 & 0.57 & 2.09 & 0.54 & 2.13 & 0.94 & 0.93 & 0.85 & 1.43 \\
\hline 1.15 & 0.98 & 1.50 & 1.25 & 0.94 & 1.91 & 0.81 & 2.00 & 1.14 & 0.85 & 1.17 & 1.20 \\
\hline \multirow[t]{2}{*}{1.66} & 0.75 & & & 1.25 & 1.78 & 1.14 & 1.86 & 1.35 & 0.77 & 1.35 & 1.13 \\
\hline & & & & & & 1.47 & 1.73 & & & & \\
\hline
\end{tabular}

${ }^{a} \mathrm{LiBr}$ concentration constant and model compound concentration variable; ${ }^{7} \mathrm{Li}$ chemical shifts against $4.0 \mathrm{M}$ aqueous $\mathrm{LiClO}_{4}$ solution. $M$ is the concentration of the model compound $(\mathrm{mol} / \mathrm{L})$; estimated accuracy of $\delta\left({ }^{7} \mathrm{Li}\right): 2 \times 10^{-2} \mathrm{ppm}$. ${ }^{b} 0.10 \mathrm{M} \mathrm{LiBr} .{ }^{c} 0.58 \mathrm{M} \mathrm{LiBr} .{ }^{d} 0.13 \mathrm{M} \mathrm{LiBr}$. ${ }^{e} 0.40 \mathrm{M} \mathrm{LiBr}$. $f 0.11 \mathrm{M} \mathrm{LiBr}$. ${ }^{g} 0.45 \mathrm{M} \mathrm{LiBr}$.

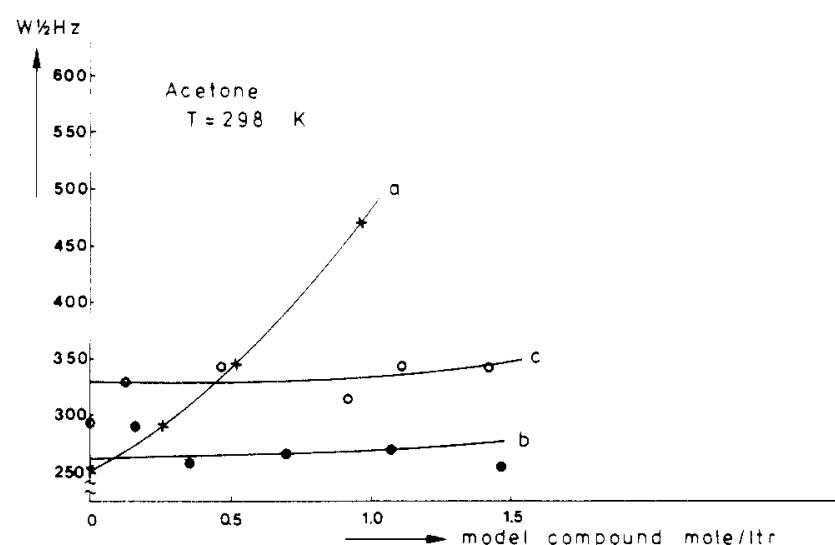

Figure 14. 24.507-MHz chlorine-35 line widths of salt-phosphate aggregates in acetone. LiCl concentration saturated ( $0.08 \mathrm{~mol} / \mathrm{L})$ : (a) $0.08 \mathrm{M} \mathrm{LiCl} / 3$, (b) $0.08 \mathrm{M} \mathrm{LiCl} / 4$, (c) $0.08 \mathrm{M} \mathrm{LiCl} / 1$.

addition, $\mathrm{CNDO} / 2$ calculations on the $1: 1$ salt-phosphate aggregates reveal a concomitant decrease in the net atomic charge of the ${ }^{7} \mathrm{Li}$ nucleus $(0.3 \mathrm{eu})$ in comparison with the free lithium salt (close-ion pair). This large decrease in net atomic charge and the increased sterical hindrance in the case of $2: 1,3: 1$, and $4: 1$ phosphate-salt aggregates suggest that the latter structures become highly unlikely.

Figures $14-16$ show ${ }^{35} \mathrm{Cl}$ and ${ }^{81} \mathrm{Br}$ line widths plotted vs. the model compound concentration, while the salt concentration is kept constant. The model compounds 1 and 4 reveal no extreme concentration dependence in the line widths, whereas 3 shows a different deportment (viz., Figure 14). Compound 3 reveals a high tendency to pen-

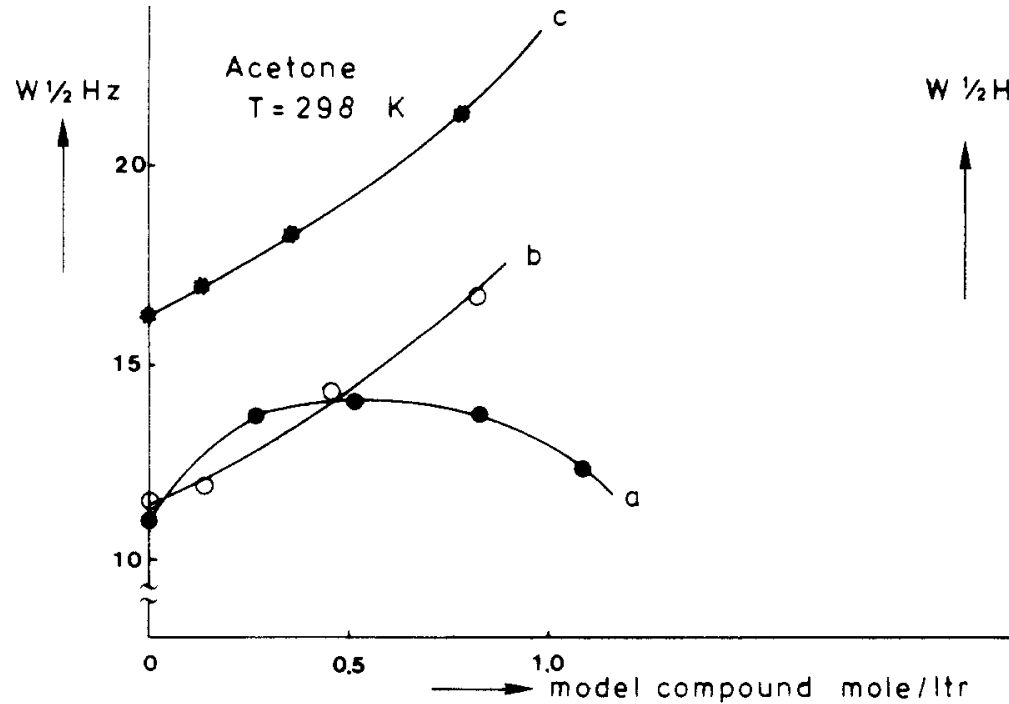

TABLE VII: 97.21-MHz Lithium·7 Chemical Shifts (ppm) of Salt/Phosphate Aggregates in Acetone at $T=298 \mathrm{~K}^{a}$

\begin{tabular}{|c|c|c|c|c|c|}
\hline \multicolumn{2}{|c|}{1} & \multicolumn{2}{|c|}{3} & \multicolumn{2}{|c|}{4} \\
\hline$M^{b}$ & $\overline{\delta\left({ }^{7} \mathrm{Li}\right)^{c}}$ & $\bar{M}$ & $\delta\left({ }^{7} \mathrm{Li}\right)$ & $\bar{M}$ & $\delta\left({ }^{7} \mathrm{Li}\right)$ \\
\hline 0 & 2.27 & 0 & 2.27 & 0 & 2.27 \\
\hline 0.19 & 1.82 & 0.08 & 2.21 & 0.08 & 2.07 \\
\hline 0.34 & 1.59 & 0.42 & 2.07 & 0.21 & 1.85 \\
\hline 0.68 & 1.24 & 0.85 & 1.93 & 0.49 & 1.54 \\
\hline 1.01 & 1.02 & 1.31 & 1.81 & 0.87 & 1.30 \\
\hline 1.33 & 0.85 & & & & \\
\hline
\end{tabular}

${ }^{a} \mathrm{LiCl}$ concentration saturated $(0.08 \mathrm{~mol} / \mathrm{L})$ and model compound concentration variable; ${ }^{7} \mathrm{Li}$ chemical shift against $4.0 \mathrm{M}$ aqueous $\mathrm{LiClO}_{4}$ solution. ${ }^{b} M$ is the concentration of the model compound $(\mathrm{mol} / \mathrm{L}){ }^{c}$ Estimated accuracy of $\delta\left({ }^{7} \mathrm{Li}\right): 2 \times 10^{-2} \mathrm{ppm}$.

etrate into the solvation shell of the anion. This distortion effect is stronger in the case of the chlorine anion (Figure 14) and in the case of the perchlorate anion (Figure 15). With respect to the lithium chloride solution, the electrical anisotropy around the ${ }^{35} \mathrm{Cl}$ nucleus is enhanced because of asymmetrical solvation of the chlorine anion due to a contribution of the (Li-O-P) fragment. Weingärtner ${ }^{9}$ was not able to measure ${ }^{35} \mathrm{Cl}$ line widths of lithium chloride in acetone. The aromatic character of 3 probably causes extra ${ }^{35} \mathrm{Cl}$ line broadening via large magnetic anisotropies inherent in aromatic rings.

Observation of the ${ }^{35} \mathrm{Cl}$ line width data with increasing concentration of lithium perchlorate (viz., Figure 15b) suggests that interactions between the lithium cation and the perchlorate anion are involved. These data are in

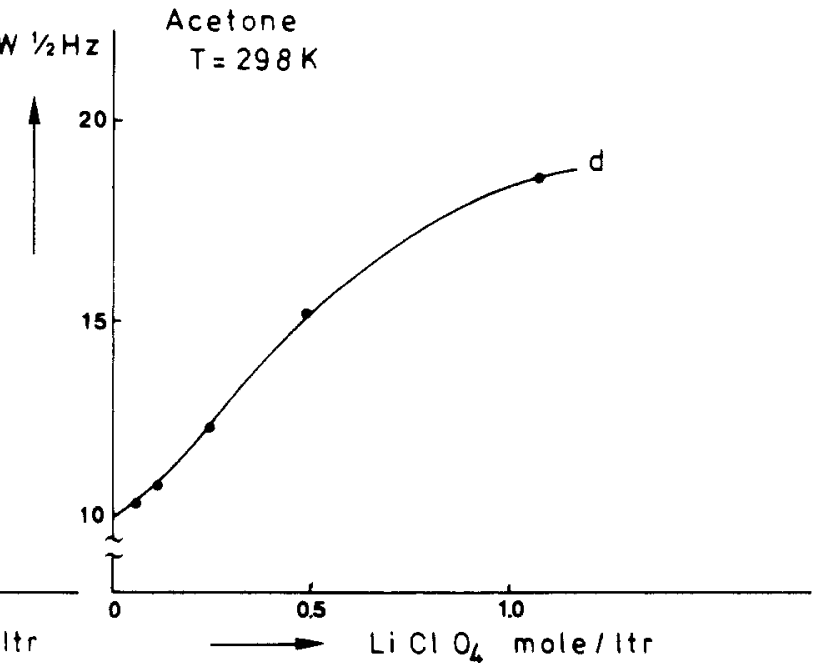

Figure 15. 24.507-MHz chlorine-35 line widths of salt-phosphate aggregates in acetone. $\mathrm{LiClO}_{4}$ concentration constant: (a) $0.12 \mathrm{M} \mathrm{LiCIO}{ }_{4} / 1$, (b) $0.12 \mathrm{M} \mathrm{LiClO}_{4} / 3$, (c) $0.58 \mathrm{M} \mathrm{LiClO}_{4} / 3$, (d) concentration of $\mathrm{LiClO}_{4}$ variable; no model compound dissolved. 
TABLE VIII: $97.21-\mathrm{MHz}$ Lithium-7 Chemical Shifts $(\mathrm{ppm})$ of Salt-Phosphate Aggregates in Acetone at $T=298 \mathrm{~K}^{a}$

\begin{tabular}{|c|c|c|c|c|c|c|c|c|c|c|c|}
\hline \multicolumn{4}{|c|}{1} & \multicolumn{4}{|c|}{3} & \multicolumn{4}{|c|}{4} \\
\hline$M^{b}$ & $\delta\left({ }^{7} \mathrm{Li}\right)$ & $M^{c}$ & $\delta\left({ }^{7} \mathrm{Li}\right)$ & $\overline{M^{d}}$ & $\delta\left({ }^{7} \mathrm{Li}\right)$ & $M^{e}$ & $\delta\left({ }^{7} \mathrm{Li}\right)$ & $M^{f}$ & $\delta\left({ }^{7} \mathrm{Li}\right)$ & $M^{g}$ & $\delta\left({ }^{7} \mathrm{Li}\right)$ \\
\hline $\begin{array}{l}0 \\
0.22 \\
0.54 \\
0.85 \\
1.00 \\
1.18\end{array}$ & $\begin{array}{l}2.25 \\
1.71 \\
1.22 \\
0.95 \\
0.85 \\
0.75\end{array}$ & $\begin{array}{l}0 \\
0.19 \\
0.36 \\
0.70 \\
1.17 \\
1.09\end{array}$ & $\begin{array}{l}2.10 \\
1.90 \\
1.71 \\
1.42 \\
1.07 \\
0.81\end{array}$ & $\begin{array}{l}0 \\
0.19 \\
0.40 \\
0.59 \\
0.89 \\
1.26\end{array}$ & $\begin{array}{l}2.27 \\
2.07 \\
1.87 \\
1.72 \\
1.52 \\
1.32\end{array}$ & $\begin{array}{l}0 \\
0.13 \\
0.31 \\
0.64 \\
0.88 \\
1.35\end{array}$ & $\begin{array}{l}2.08 \\
1.98 \\
1.85 \\
1.63 \\
1.50 \\
1.28\end{array}$ & $\begin{array}{l}0 \\
0.21 \\
0.45 \\
0.83 \\
1.17 \\
1.38\end{array}$ & $\begin{array}{l}2.26 \\
1.72 \\
1.26 \\
0.81 \\
0.66 \\
0.61\end{array}$ & $\begin{array}{l}0 \\
0.21 \\
0.37 \\
0.62 \\
0.88 \\
1.34\end{array}$ & $\begin{array}{l}2.09 \\
1.87 \\
1.73 \\
1.46 \\
1.15 \\
0.90\end{array}$ \\
\hline
\end{tabular}

${ }^{a} \mathrm{LiClO}_{4}$ concentration constant and model compound concentration variable; ${ }^{7} \mathrm{Li}$ chemical shifts against $4.0 \mathrm{M}$ aqueous $\mathrm{LiClO}_{4}$ solution. $M$ is the concentration of the model compound (mol/L); estimated accuracy of $\delta\left({ }^{7} \mathrm{Li}\right): 2 \times 10^{-2} \mathrm{ppm}$. For variable $\mathrm{LiClO}_{4}$ concentration $(\mathrm{mol} / \mathrm{L})$ in acetone without model compound the following ' $\mathrm{Li}$ chemical shifts were measured: $0.05 \mathrm{M}, 2.37 \mathrm{ppm} ; 0.10 \mathrm{M}, 2.30 \mathrm{ppm} ; 0.20 \mathrm{M}, 2.23 \mathrm{ppm} ; 0.40 \mathrm{M}, 2.15 \mathrm{ppm}$; and $0.81 \mathrm{M}, 2.05 \mathrm{ppm}$. ${ }^{b} 0.13 \mathrm{M}$ $\mathrm{LiClO}_{4} \cdot{ }^{c} 0.49 \mathrm{M} \mathrm{LiClO}_{4} \cdot{ }^{d} 0.11 \mathrm{M} \mathrm{LiClO}_{4} \cdot{ }_{e}^{e} 0.57 \mathrm{M} \mathrm{LiClO}_{4} \cdot{ }_{f} 0.12 \mathrm{M} \mathrm{LiClO}_{4} \cdot{ }_{8} 0.52 \mathrm{M} \mathrm{LiClO}_{4}$.

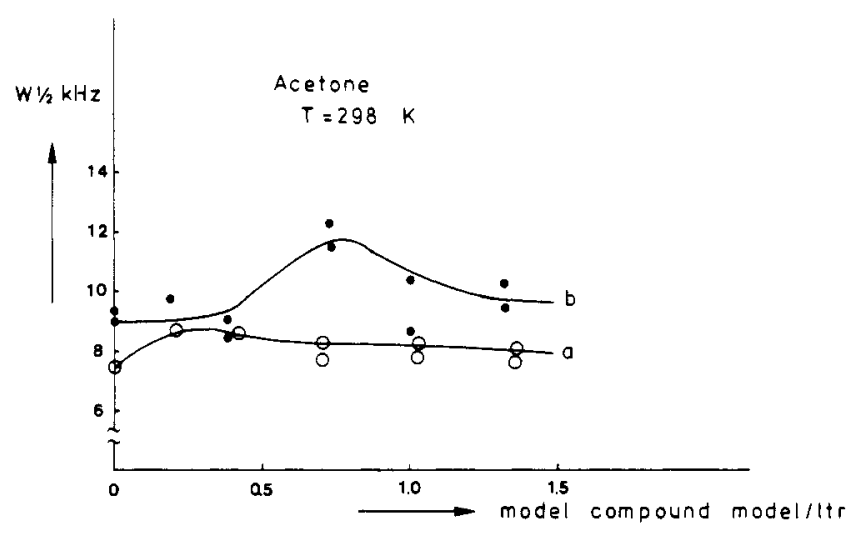

Figure 16. $67.55-\mathrm{MHz}$ bromine-81 line widths of salt-phosphate aggregates in acetone. LiBr concentration constant: (a) $0.11 \mathrm{M} \mathrm{LiBr} / 1$, (b) $0.09 \mathrm{M} \mathrm{LIBr} / 3$.

contrast with the results of Popov. ${ }^{8,39}$ As we estimate the possible error in our measured ${ }^{35} \mathrm{Cl}$ line widths on the order of $1 \mathrm{~Hz}$ in a lithium perchlorate solution, these data suggest an aromatic-solvent-induced contribution in the case of 3. This effect results in increased ${ }^{35} \mathrm{Cl}$ line widths. With respect to 1 , at least two contradictory effects must be involved which at present are not clear. Former publications from this laboratory $\mathrm{y}^{40,41}$ offered the suggestion that knowledge, achieved via physical data on model organophosphorus compounds, can also be applied to the phosphate residues in the helix backbone of the doublestranded DNA molecule. A model was presented for the salt-induced transition of right-handed B-DNA into lefthanded Z-DNA assuming long-lived phosphate-salt complexes. ${ }^{42,43}$ Careful study of small DNA fragments in aqueous salt solutions by means of multinuclear NMR techniques may give additional information.

\section{Conclusions}

(1) Kinetic experiments revealed that phosphorylation of 2 is retarded by addition of lithium halides. The magnitude of the effect is correlated to the ionic radius as well as to the solvation properties (larger solvation shells result in more efficient screening of the phosphorus atom).

(40) Buck, H. M.; van Aken, D.; van Lier, J. J. C.; Kemper, M. J. H. Recl. Trav. Chim. Pays-Bas 1980, 99, 183.

(41) Buck, H. M. Recl. Trav. Chim. Pays-Bas 1981, 100, 217.

(42) van Lier, J. J. C.; Koole, L .H.; Buck, H. M. Recl. Trav. Chim. Pays-Bas 1983, 102, 148 .

(43) van Lier, J. J. C.; Smits, M. T.; Buck, H. M. Eur. J. Biochem. $1983,132,55$.
(2) ${ }^{1} \mathrm{H}$ NMR spectra of $\mathrm{Eu}(\text { fod })_{3}$ complexes of 1 confirm the intrinsic magnetic inequivalence of the ring methylene protons. In retrospect earlier results from this laboratory ${ }^{10}$ can be explained similarly. Addition of lithium halides to solutions of 1 causes effects which are superficially analogous but which are related to solvent reorientation in the vicinity of the ring methylene protons.

(3) Accurate values of ${ }^{2} J_{\mathrm{HH}}{ }^{21}$ determined via computer simulation of ${ }^{1} \mathrm{H}$ NMR spectra of 1 in different environments (acetone, benzene, acetone/lithium bromide) revealed a negligible change in the net atomic charge on the phosphorus atom. This conclusion seems consistent with the small ( $\sim 1 \mathrm{ppm})^{31} \mathrm{P}$ chemical shift differences which occur upon addition of salt to the phosphates.

Our low-temperature ${ }^{31} \mathrm{P}$ NMR results (in which 2 and lithium fluoride or sodium fluoride were dissolved in THF) showed no ${ }^{1} J_{\mathrm{PF}}$ in the temperature range $213-298 \mathrm{~K}$. This indicates that no covalent P-F bonds are formed.

In addition, different geometries of 2 with 1 equiv of $\mathrm{LiBr}$ were calculated by the CNDO/ 2 method (Figure 12, $\mathrm{a}-\mathrm{c}) .{ }^{27}$ Optimization toward lowest total energy revealed a decreasing stability in the order $a>b>c$. This implies a short-living $\mathrm{P}^{\mathrm{V}}$-like structure as a result of the interaction of the d orbitals of phosphorus with the unpaired electron pairs of the bromine (Figure 12c). The close-ion-pair aggregate (Figure 12a) seems the most stable, NMR-observed configuration.

(4) ${ }^{7} \mathrm{Li}$ NMR spectra of several lithium halides in a number of organic solvents are consistent with earlier work of Popov and Weingärtner. ${ }^{8}$ The same is true for the ${ }^{35} \mathrm{Cl}$ and ${ }^{81} \mathrm{Br}$ NMR measurements of the anions with the exception of the ${ }^{35} \mathrm{Cl}$ NMR results of lithium chloride in acetone. The ${ }^{7} \mathrm{Li},{ }^{35} \mathrm{Cl}$, and ${ }^{81} \mathrm{Br}$ NMR results can be explained assuming fast equilibria between lithium halides in the complexed (with phosphates) and free forms. There seems to be a preference for $1: 1$ complexes of lithium halides and the phosphates studied here.

Acknowledgment. This investigation was supported by the Netherlands Foundation for Chemical Research (SON) with financial aid from the Netherlands Organization for the Advancement of Pure Research (ZWO). We thank Mrs. Hanneke Becht, Mr. Jacques Stroucken, and Mr. Piet Traa for their assistance in kinetic experiments and Dr. Gerrit Visser for the stereoscopic drawing (Figure 5).

Registry No. 1, 63630-61-5; 2, 933-43-7; 3, 115-86-6; 4, 78-40-0; $\mathrm{LiClO}_{4}, 7791-03-9 ; \mathrm{LiBr}, 7550-35-8 ; \mathrm{LiCl}, 7447-41-8 ; \mathrm{LiF}, 7789-24-4$; $\left(\mathrm{CD}_{3}\right)_{2} \mathrm{SO}, 2206-27-1 ; \mathrm{CD}_{2} \mathrm{Cl}_{2}, 1665-00-5 ; \mathrm{CDCl}_{3}, 865-49-6 ; \mathrm{CD}_{3} \mathrm{NO}_{2}$, 13031-32-8; $\left(\mathrm{CD}_{3}\right)_{2} \mathrm{CO}, 666-52-4 ; \mathrm{C}_{6} \mathrm{D}_{6}, 1076-43-3 ; \mathrm{SO}_{2}, 7446-09-5$. 